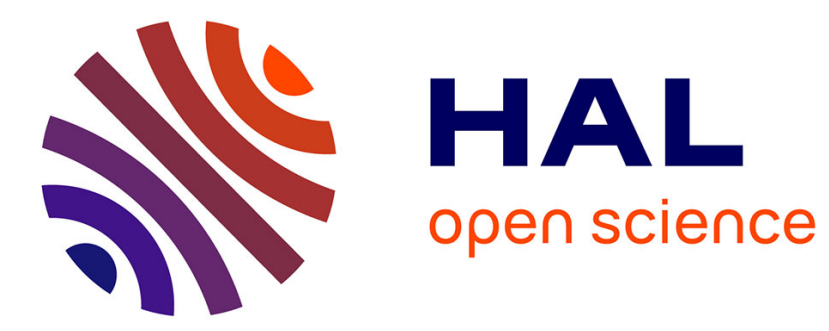

\title{
Cytotoxicity Testing of Endodontic Sealers: A New Method
}

\author{
Jean Camps, Imad About
}

\section{To cite this version:}

Jean Camps, Imad About. Cytotoxicity Testing of Endodontic Sealers: A New Method. Journal of Endodontics, 2003, 29 (9), pp.583-586. 10.1097/00004770-200309000-00010 . hal-03552420

\author{
HAL Id: hal-03552420 \\ https://hal.science/hal-03552420
}

Submitted on 2 Feb 2022

HAL is a multi-disciplinary open access archive for the deposit and dissemination of scientific research documents, whether they are published or not. The documents may come from teaching and research institutions in France or abroad, or from public or private research centers.
L'archive ouverte pluridisciplinaire HAL, est destinée au dépôt et à la diffusion de documents scientifiques de niveau recherche, publiés ou non, émanant des établissements d'enseignement et de recherche français ou étrangers, des laboratoires publics ou privés. 


\title{
Cytotoxicity Testing of Endodontic Sealers: A New Method
}

\author{
Jean Camps, DCD, PhD, and Imad About, PhD
}

The purpose of this study was to compare ISO standards versus a new technique for in vitro evaluation of cytotoxicity of root canal sealers. The cytotoxicity of AH Plus, Cortisomol, and Sealapex was first recorded according to ISO standards on L 929 fibroblasts by the MTT assay. In parallel, 30 single-rooted teeth were cut at the cementum enamel junction (CEJ), and the roots were prepared and sterilized before filling with the lateral condensation using one of three sealers $(n=10)$. The apexes of the roots were dipped into $1 \mathrm{ml}$ of minimum essential medium for 1,2 , and 30 days renewing the medium every other day. After 24-h contact between the medium and the filled roots, the medium was used to measure the cytotoxicity on L 929 with the MTT assay. ISO standards always gave a statistically higher cytotoxicity than the root-dipping technique ( $p<0.0001$ ), whatever the sealer and the exposure time. The ISO standards showed statistically significant differences among the sealers $(p<0.0001)$. AH Plus was noncytotoxic, Cortisomol showed a high cytotoxicity decreasing over time ( $p<0.001)$, and Sealapex displayed a high cytotoxicity that did not decrease over time (NS). The new technique showed statistically significant differences among the sealers $(p=0.001)$, but the differences were so small that they were likely not clinically relevant. The high cytotoxicity of Sealapex decreased over time but the cytotoxicity of AH Plus and Cortisomol did not. The results show that the ISO standards may strongly over-evaluate the cytotoxicity of the endodontic sealers, emphasize the difference among the sealers, and may clinically correspond to a large overfilling. The new technique reduces the discrimination of the test and may clinically correspond to a classical filling. Therefore, both methods might be considered as clinically relevant, corresponding to classical and overfilling conditions.
Several studies showed that endodontic sealers are indispensable to achieve a hermetic apical seal (1). They serve as lubricant, fill the irregularities between the dentinal walls and the gutta-percha core, as well as the lateral or accessory canals, and bond both to gutta-percha and dentin (2). Their mechanical and physical properties must meet defined requirements (3). Because they are placed in contact for many years with living tissues, they also must be biocompatible (4).

Among initial tests, genotoxicity (5) and mutagenicity (6) are not frequently evaluated compared with cytotoxicity that has been extensively tested. The ISO standards give general guidelines on the design of this kind of study. The samples of sealer must be stored for 1 to 3 days in culture medium, and the surface/medium ratio should be 0.5 to $6.0 \mathrm{~cm}^{2} / \mathrm{ml}$. The strict application of this technique presents drawbacks and should be applied under conditions simulating in vivo conditions as much as possible. This can easily be demonstrated by the fact that the required surface of contact between the sealer and the medium is not clinically relevant. For example, a $0.2-\mathrm{mm}$ in diameter apex yields an area of $0.03 \mathrm{~mm}^{2}$. Although this surface does not take into account the area of the gutta-percha cone, it is 1,600 to 20,000 times smaller than the surface used when working with ISO standards. The surface of contact is so largely over-evaluated that the cytotoxicity recorded is likely over-evaluated in the same manner, because cytotoxicity is a dose-dependant phenomenon. Added to the natural tendency of in vitro cytotoxicity tests toward over-estimation (7), this shows that ISO standards give an estimated cytotoxicity that is very likely not clinically relevant. That may be why some perfectly well tolerated sealers, clinically used for decades, are rated as cytotoxic materials when tested in vitro (8).

The design of the in vitro cytotoxicity tests for restorative materials has been largely improved. Nowadays these tests take into account many clinical factors such as dentin interposition (9), pulpal pressure simulation (10), three-dimensional cultures (11), and pulpal clearance (12). Surprisingly the design of in vitro cytotoxicity tests for endodontic sealers did not evolve. The simple elution of the sealer in the culture medium remains the most commonly used technique. Instead of extracting the cytotoxic components from endodontic sealers in a liquid vehicle, some authors interposed agar (13) or a polycarbonate membrane (14) between the sealers and the target cells. This remains rather far from clinical conditions, which can be better imitated by dipping a filled root in the culture medium to allow elution of the sealer into the medium through the apex of a natural tooth: the so-called root-dipping technique in this article. 
The purpose of this study was to compare the cytotoxicity of three root canal sealers tested with ISO standards versus the root-dipping technique. The null hypothesis is that the cytotoxicity of the root canal sealers is much higher when tested with the ISO standards versus the root-dipping technique.

\section{MATERIALS AND METHODS}

\section{ISO Standards 10993-5}

Three sealers were tested: a zinc-oxide-eugenol-based sealer: Cortisomol (Pierre Rolland, Merignac, France) (batch number 755); a calcium hydroxide-based sealer: Sealapex (Kerr, Romulus, MI) (batch number 0-1307); and an epoxy resin-based sealer: $\mathrm{AH}$ Plus (DeTrey Dentsply, Konstanz, Germany) (batch number 0010000421). Ten samples for each sealer were prepared according to the manufacturer recommendations and stored in an incubator before sterilization with UV rays. The samples were stored in $1 \mathrm{ml}$ of minimum essential medium (Gibco, Cergy-Pontoise, France) with $10 \%$ fetal calf serum (Biowhittaker, Gagny, France) supplemented with $50 \mathrm{IU} / \mathrm{ml}$ of penicillin, $50 \mu \mathrm{g} / \mathrm{ml}$ of streptomycin, and 0.2 moles/L of glutamine. According to ISO standards, the ratio between the surface of the sample and the volume of medium was of $0.5 \mathrm{~cm}^{2} / \mathrm{ml}$. This medium, containing the sample, is called the test medium. L 929 fibroblasts were plated at 30,000 cells $\mathrm{cm}^{-2}$ in 96-well plates (Falcon 3072, Becton Dickinson, Oxford, GB). The 96-well dishes were then placed into a humid incubator with an atmosphere of $5 \% \mathrm{CO}_{2}, 95 \%$ air for $24 \mathrm{~h}$ before use. After this 24 -h period, the medium from the 96 -well plates was removed and replaced by the test medium. At that time, the 96-well plates were placed in an incubator again for $24 \mathrm{~h}$. A succinyl dehydrogenase assay (MTT) was performed on the dishes after $24 \mathrm{~h}$ of incubation (i.e. $48 \mathrm{~h}$ after the beginning of the experiment). The medium was removed and immediately replaced with $100 \mu \mathrm{l} /$ well of a $0.5 \%$ solution of 3-(4,5-dimethylthiazol-2-yl)-2,(-diphenyl tetrazolium bromide) (Sigma Chemical Co., St. Louis, MO) in medium. After incubation for $2 \mathrm{~h}$ at $37^{\circ} \mathrm{C}$, the supernatant was discarded, and the formazan crystals were solubilized with 100 $\mu \mathrm{l} /$ well of dimethylsulfoxide (DMSO, Sigma Chemical Co.). The absorbance of each 96-well dish was determined using an automatic microplate spectrophotometer (E 960, Bioblock, Strasbourg, France) at $550 \mathrm{~nm}$. The absorbance of the wells containing the same medium was averaged as a single measurement and calculated against the control medium.

The same experiment was performed at 1,2, and 30 days. For 2 and 30 days the medium was renewed every other day. The last medium in contact with the sealer for $24 \mathrm{~h}$ was the test medium and was used to measure the cytotoxicity under the same conditions.

\section{Root-Dipping Technique}

Thirty intact monoradicular teeth, freshly extracted, were stored at $4{ }^{\circ} \mathrm{C}$ and used for this study. The crowns were removed at the cementodentinal junction with a diamond disk under water coolant. A \#10 K-file was introduced into the canal to radiographically measure the working length and to check the patency of the apex. The root canals were prepared by the same operator at the cementodentinal junction with a ProFile device (Maillefer, Ballaigues, Switzerland) using a reduction handpiece powered by an electric motor following the sequence: ProFile.taper 06 \#30, \#25, and \#20;
TABLE 1. Cytotoxicity of three root canal sealers determined by ISO standards

\begin{tabular}{lrrrc}
\hline \multirow{2}{*}{$\begin{array}{c}\text { Root Canal } \\
\text { Sealer }\end{array}$} & \multicolumn{3}{c}{ Cytotoxicity (Percentage of Cell Mortality) } \\
\cline { 2 - 5 } & 1 day & 2 days & 30 days & $\begin{array}{c}\text { Decrease } \\
\text { Over Time }\end{array}$ \\
\hline AH Plus & $0 \pm 4^{\mathrm{a}}$ & $0 \pm 4^{\mathrm{a}}$ & $0 \pm 4^{\mathrm{a}}$ & $\mathrm{NS}$ \\
Cortisomol & $95 \pm 1^{\mathrm{b}}$ & $50 \pm 1^{\mathrm{b}}$ & $29 \pm 3^{\mathrm{b}}$ & $\mathrm{p}<0.001$ \\
Sealapex & $96 \pm 1^{\mathrm{b}}$ & $96 \pm 1^{\mathrm{c}}$ & $91 \pm 1^{\mathrm{c}}$ & $\mathrm{NS}$ \\
\hline
\end{tabular}

Groups with the same superscript letter are not statistically significant. NS = not significant.

ProFile.taper 04 \#25 and \#20; ProFile.taper 06 \#20, \#25, and \#30. A \#10 K-file was used between each ProFile to verify the apex patency. The irrigant was $2.5 \% \mathrm{NaOCl}$ delivered with a 27 -gauge needle, $2 \mathrm{ml}$ between each file size.

The teeth were then sterilized at $135^{\circ} \mathrm{C}$ for $35 \mathrm{~min}$ (15). After sterilization the 30 teeth were randomly divided into three groups of 10 teeth to be filled with gutta-percha using the lateral condensation technique using one of the three sealers already used for the ISO standards. This was performed under sterile conditions in a laminar flow hood. The teeth were then stored for 1 day in an incubator at $37^{\circ} \mathrm{C}$ and $100 \%$ humidity to allow setting of the endodontic sealers.

The apex of the roots was dipped into $1 \mathrm{ml}$ of culture medium for 1,2 , and 30 days renewing the medium every other day. The last medium, which remained in contact with the apex for $24 \mathrm{~h}$, was the test medium and was used to measure the cytotoxicity under the same conditions as for ISO standards: the respiratory function of L 929 fibroblasts being evaluated by the MTT assay.

\section{Statistical Analysis}

Two-way ANOVA was not possible because of interactions between the two factors (sealer and exposure time).

1. Comparison of both techniques: one ANOVA for each sealer and each time was performed.

2. Comparison of sealers: one ANOVA for each technique and each time, followed by Duncan's multiple range test, was performed.

3. Comparison of exposure times: one ANOVA for each technique and each sealer, followed by Duncan's multiple range test, was performed.

Statistical significance was defined as $\mathrm{p}<0.05$.

\section{RESULTS}

\section{Comparison of Techniques}

Except for noncytotoxic AH Plus, ANOVA showed a higher cytotoxicity of the sealers when tested with ISO standards versus the root-dipping technique $(\mathrm{p}<0.0001)$.

\section{Comparison of Sealers}

With ISO standards, the three ANOVAs showed a statistically significant difference among the sealers at 1,2 , and 30 days $(\mathrm{p}<$ 0.0001) (Table 1). Duncan's test showed that Cortisomol and Sealapex were more cytotoxic than AH Plus at 1 day $(\mathrm{p}<0.001)$, 
TABLE 2. Cytotoxicity of three root canal sealers determined by the root-dipping technique

\begin{tabular}{lrrrc}
\hline \multirow{2}{*}{$\begin{array}{c}\text { Root Canal } \\
\text { Sealer }\end{array}$} & \multicolumn{3}{c}{ Cytotoxicity (Percentage of Cell Mortality) } \\
\cline { 2 - 5 } & 1 day & 2 days & 30 days & $\begin{array}{c}\text { Decrease } \\
\text { Over Time }\end{array}$ \\
\hline AH Plus & $6 \pm 2^{\mathrm{c}}$ & $5 \pm 2^{\mathrm{b}}$ & $7 \pm 2^{\mathrm{b}}$ & $\mathrm{NS}$ \\
Cortisomol & $15 \pm 5^{\mathrm{a}}$ & $12 \pm 4^{\mathrm{a}}$ & $10 \pm 4^{\mathrm{a}}$ & $\mathrm{NS}$ \\
Sealapex & $9 \pm 7^{\mathrm{b}}$ & $0 \pm 4^{\mathrm{c}}$ & $0 \pm 3^{\mathrm{c}}$ & $\mathrm{p}<0.001$ \\
\hline
\end{tabular}

Groups with the same superscript letter are not statistically significant.

NS $=$ not significant.

but Sealapex was more cytotoxic than Cortisomol, which in turn was more cytotoxic than AH Plus at 2 and 30 days ( $<<0.001)$.

With the root-dipping technique, the three ANOVAs showed a statistically significant difference among the sealers at 1,2 , and 30 days $(\mathrm{p}=0.001)$ (Table 2). Duncan's test showed that Cortisomol was more cytotoxic than Sealapex, which was more cytotoxic than AH Plus at 1 day $(\mathrm{p}=0.001)$, but Cortisomol was more cytotoxic than AH Plus, which in turn was more cytotoxic than Sealapex at 2 and 30 days $(p=0.001)$. However, the cell death percentages were so low that the sealers can be considered noncytotoxic according to this technique.

\section{Comparison of Exposure Times}

With ISO standards, the cytotoxicity of AH Plus and Sealapex did not vary over time (NS), whereas that of Cortisomol decreased with time $(\mathrm{p}<0.001)$. With the root-dipping technique, the cytotoxicity of AH Plus and Cortisomol did not decrease over time (NS), whereas that of Sealapex decreased over time $(\mathrm{p}<0.001)$.

\section{DISCUSSION}

Four families of root canal sealers are available: zinc oxideeugenol-based sealers, calcium hydroxide-based sealers, epoxy resin-based sealers, and glass-ionomer cements. They have been used for many years and seem to give acceptable clinical results. All recent root canal sealers are not fundamentally different and are always related to these four families. Therefore, killing animals to test in vivo biocompatibility of new endodontic sealers is ethically difficult to defend. In addition, cytotoxicity studies of endodontic materials are considered indispensable by ISO standards to minimize the number of laboratory animals. Therefore, this kind of experiment is used as often as new root canal sealers are released.

The results of this study confirm the null hypothesis: ISO standards lead us to accept the cytotoxicity of endodontic sealers that were rated noncytotoxic when tested with the root-dipping technique. For example, Sealapex showed a high cytotoxicity ranging from $91 \%$ to $96 \%$ of cell death when evaluated with ISO standards, whereas a cytotoxicity ranging from $0 \%$ to $9 \%$ was observed when working with the other technique. This discrepancy between the results could have been even more pronounced because we chose the lowest ratio between the surface of the sample and the volume of culture medium given by ISO standards $\left(0.5 \mathrm{~cm}^{2} / \mathrm{ml}\right)$.

This was expected because cytotoxicity increases with the concentration. This has been shown for instance with the eugenol released from zinc oxide-based materials (16). Increasing the surface of contact between the root canal sealer and the medium increases the amount of leaching molecules within the medium and their cytotoxicity. Therefore complying with ISO standards leads us to classify as cytotoxic some root canal sealers that have been successfully used for many years. Under these conditions, the results of this kind of experiment are questionable. The ISO standards so often give false-positive responses that we may even consider a cytotoxic root canal sealer favorably and thus accept questionable new root canal sealers. That is why ISO standards (4) specify in the guidance for the selection of tests that these tests should be applied "with the interpretation and judgement by the appropriate professionals taking into consideration the factors relevant to the material, its intended use and the current knowledge of the material provided by the scientific literature and previous clinical experience." In line with this fundamental idea we must keep in mind that large overfillings are possible, especially when a periapical lesion modifies the anatomy of the apex. Under these special conditions, the ratio between the filling material and the target cells may highly increase and be closer to the ISO standard requirements. Thus we must consider that both techniques of evaluation are complementary and necessary. The ISO standards give information on what may happen with large overfillings, whereas the root-dipping technique brings information on current cases.

The ISO standards showed very large differences among the sealers, whereas the new technique showed such a small statistically significant difference that it was likely clinically irrelevant. Two prospective studies on human teeth showed no statistically significant difference between a zinc oxide-based sealer and AH 26 after $4 \mathrm{yr}(16,17)$. This confirms the results obtained with the root-dipping technique and is in contraindication with those obtained with the ISO standards.

This study showed the importance of the simulation of clinical conditions during in vitro evaluation of material properties. The protocol used in this study could be improved in future studies. Different cells behave differently when used for cytotoxicity evaluation, thus periodontal fibroblasts and osteoblasts could be used as target cells because they are clinically relevant (18). Inflammatory cells also could be used to determine if the components leaching from the root canal sealers do not interfere with the cells involved in the inflammatory response involved in periapical healing (19). The volume of periapical liquids and their clearance could be reproduced. The composition and $\mathrm{pH}$ of the periapical liquid also should be considered.

The evolution of cytotoxicity with time also is an important factor to take into account. The ISO standard test showed that the cytotoxicity of zinc oxide-based root canal sealer decreased over time in parallel with the rate of eugenol (20). On the contrary, the cytotoxicity of Sealapex did not decrease. This may be related to the high solubility of the set material, which led to a more pronounced dissolution of the material in the culture medium. The AH Plus sealer did not show any variation of cytotoxicity over time because it was either nonexistent according to ISO standard or near zero according to the rootdipping technique.

Drs. Camps and About are affiliated with Unité IMEB, Faculté d'Odontologie, Cedex, France.

Address requests for reprints to Dr. Jean Camps, Faculté d'Odontologie, 27 boulevard Jean Moulin, 13385 Marseille CEDEX 5, France. 


\section{References}

1. Skinner RL, Van Himmel T. The sealing ability of injection-molded thermoplasticized gutta-percha with and without the use of sealers. J Endodon 1987;13:315-7.

2. Lee KW, Williams MC, Camps J, Pashley D. Adhesion of endodontic sealers to dentin and gutta-percha. J Endodon 2002;28:684-8.

3. ISO standards 6876 . Dental root canal sealing materials.

4. ISO standards 10993-5. Biological evaluation of medical devices. Tests for cytotoxicity: in vitro methods.

5. Tai KW, Huang FM, Huang MS, Chang YC. Assessment of the genotoxicity of rein and zinc-oxide eugenol-based root canal sealers using an in vitro mammalian test system. J Biomed Mater Res 2002;59:73-7.

6. Ersev H, Schmalz G, Bayirli G, Schweikl H. Cytotoxic and mutagenic potencies of various root canal filling materials on eukaryotic and prokaryotic cells in vitro. J Endodon 1999;25:359-63.

7. Browne RM. The in vitro assessment of the cytotoxicity of dental materials: does it have a role? Int Endod J 1988;21:50-8.

8. Telli C, Serper A, Dogan AL, Guc D. Evaluation of the cytotoxicity of calcium phosphate root canal sealers by MTT assay. J Endodon 1999;25: 811-3.

9. Camps J, Cosset A, Abou Hashieh I, Dejou J, Franquin JC. Influence of hydraulic conductance of dentine on in vitro cytotoxicity testing. J Dent 1998;26:473-7.

10. Camps J, Tardieu C, Dejou J, Ladaique P, Rieu R, Franquin JC. In vitro cytotoxicity of dentin bonding agents under simulated physiological conditions. Dent Mater 1997;13:34-42.

11. Schuster U, Schmalz G, Thonemann B, Mendl N, Metzl C. Cytotoxicity testing with three-dimensional cultures of transfected pulp-derived cells. Endodon 2001;27:259-65.

12. Camps J, Thonemann B, About I, Franquin JC, Schmalz G. Two dimension versus three dimension in vitro odontoblast-like cell cytodifferentiation. Connec Tissue Res 2002;43:396-400.

13. Cohen BI, Pagnillo MK, Musikant BL, Deutsch AS. An in vitro study of the cytotoxicity of two root canal sealers. J Endodon 2000;26:228-9.

14. Guigand M, Pellen-Mussi P, Le Goff A, Vulcain JM, Bonnaure-Mallet M. Evaluation of the cytocompatibility of three endodontic materials. J Endodon 1999;25:419-23.

15. De Wald JP. The use of extracted teeth for in vitro bonding studies. A review of infection control considerations. Dent Mater 1997;13:74-81.

16. Orstavik D, Kerekes K, Eriksen HM. Clinical performance of three endodontic sealers. Endod Dent Traumatol 1987;3:178-86.

17. Waltimo TM, Boiesen J, Eriksen HM, Orstavik D. Clinical performance of 3 endodontic sealers. Oral Surg Oral Med Oral Pathol 2001;92:89-92.

18. Huang FM, Tai KW, Chou MY, Chang YC. Cytotoxicity of resin-, zinc oxide-eugenol, and calcium hydroxide-based root canal sealers on human periodontal ligament cells and permanent V' cells. Int Endod J 2002;35:153-8

19. Effect of three calcium hydroxide-based materials on human blood monocytes and lymphocytes. Endod Dent Traumatol 1987;3:28-32.

20. Abou Hashieh I, Pommel L Camps J. Concentration of eugenol apically released from zinc oxide-based sealers. J Endodon 1999;25:713-5. 